\title{
COMPARISON BETWEEN ROLLER-BALL ENDOMETRIAL ABLATION AND LEVONORGESTREL INTRAUTERINE SYSTEM (LNG-IUS) IN THE TREATMENT OF ABNORMAL UTERINE BLEEDING
}

\author{
Bulent ERGUN, Oguzhan KURU, Serhat SEN, Yusuf KILIC
}

Department of Gynecology and Obstetric, Faculty of Medicine, Istanbul University, Istanbul, Turkey

\begin{abstract}
SUMMARY
Objectives: To compare the efficacy, adverse effects and user satisfaction of roller-ball endometrial ablation (RBEA) and levonorgestrel intrauterin system (LNG-IUS) for the treatment of abnormal uterine bleeding (AUB). Material and methods: 58 women attending a university hospital clinic in Istanbul,Turkey were randomised to either surgical treatment using RBEA or medical treatment using a LNG-IUS (Mirena, Schering Healthcare). Pictorial bleeding assesment chart (PBAC) scores and hemoglobin levels were noted pre-insertion/operatively and again at one year post-insertion/operatively. Non-parametric tests (Mann-Whitney) and Pearson chi-square test were used for statistical analysis. Ethics Commitee approval was obtained for this study.

Results: Hemoglobin levels were increased and PBAC scores were reduced in both groups after 1 year of treatment $(p<0.05)$. But there was no statistical difference between the groups.

Conclusion: Both the RBEA and LNG-IUS are effective in the treatment of AUB. The choice of treatment should be tailored to the woman's needs and preferences.
\end{abstract}

Key words: abnormal uterine bleeding, levonorgestrel intrauterine system, roller-ball endometrial ablation

Journal of Turkish Society of Obstetrics and Gynecology, (J Turk Soc Obstet Gynecol), 2011; Vol: 8 Issue: 4 Pages: 259- 63

\section{ANORMAL UTERIN KANAMADA ROLLER-BALL ENDOMETRIAL ABLASYON VE LEVONORGESTREL INTRAUTERIN SISTEM (LNG-IUS) TEDAVILERININ KARŞILAŞTIRILMASI}

ÖZET

Amaç: Anormal uterin kanamada kullantlan roller-ball endometrial ablasyon (RBEA) ve levonorgestrel intrauterin sistem (LNG-IUS) tedavilerini; etkinliği, yan etkileri ve hasta memnuniyeti açısından kıyaslamak.

Gereç ve yöntemler: Polikliniğimize başvuran 58 hasta, cerrahi tedavi olarak RBEA veya medikal tedavi olarak LNGIUS arasında randomize edildi. Prosedürlerden önce ve 1 yll sonra Hb değerleri ile Resimsel Kanama Değerlendirme Kartı (RKDK) skorları not edildi. İstatistiksel analiz olarak non-parametrik testler (Mann-Whitney) ve Pearson kikare testi kullanıldı. Çalışma için etik kurul onayı alındı.

Bulgular: Birinci sene sonunda her iki grupta da Hb seviyelerinde artış ve RKDK skorlarında azalma saptandı (p<0.05). Fakat iki grup arasinda istatistiksel fark bulunmadi.

Sonuç: Hem RBEA hem de LNG-IUS anormal uterin kanamada histerektomiye alternatif etkili ve az invaziv tedavi seçenekleridir. Hastanın ihtiyacı ve tercihine göre karar verilmelidir.

Anahtar kelimeler: anormal uterin kanama, levonorgestrel intrauterin sistem, roller-ball endometrial ablasyon Türk Jinekoloji ve Obstetrik Derneği Dergisi, (J Turk Soc Obstet Gynecol), 2011; Cilt: 8 Sayl: 4 Sayfa: 259-63

Address for Correspondence: Bülent Ergün. İstanbul Üniversitesi İstanbul Tıp Fakültesi, Kadın Hastalıkları ve Doğum Anabilim Dalı, İstanbul Phone.: + 90 (532) 2772400

e-mail: bergyn@uydunet.net

Received: 26 January 2011, revised: 28 July 2011, accepted 11 August 2011, online publication: 23 August 2011 


\section{INTRODUCTIOON}

The spectrum of abnormal uterine bleeding affects $20-30 \%$ of women in perimenopausal period and is therefore the most common complaint seen by gynaecologists $(1,2)$. While pharmacological approach is the very first option in treatment, the success rates of teratment show variability and a significant number of patients don't respond to conservative treatments. As a consequence, about 180.000 hysterectomies are performed in the United States each year ${ }^{(3-5)}$. Even though hysterectomy cures the menorrhagia precisely, postoperative complication rates are about $\% 9$ and $\% 1$ of these are critical ; the mortality rate is around 0.38 per $1000^{(6)}$.

It is the goal of modern medicine to find and use efficacious and less invasive technics in the treatment of abnormal uterine bleeding, which can make the patients return to their daily activities sooner(7). Endometrial ablation mainly causes permanent destruction of endometrium, which has a success rate of $85-90 \%$ even in long term ${ }^{(8,9)}$. Levonorgestrel intrauterine system (LNG - IUS), an intrauterine hormone system, is an efficacious option for treatment, which is used with the patients who have no benefit from oral hormone therapy ${ }^{(10)}$. In this study, we aimed to compare roller-ball endometrial ablation (RBEA) and levonorgestrel intrauterin system (LNG-IUS) for the treatment of abnormal uterine bleeding (AUB), in that we evaluate the methods in terms of hemoglobin levels, bleeding patterns, amount of blood loss and rates of satisfaction.

\section{MATERIAL AND METHODS}

The patients applied to our Gynaecology clinic between February and August 2009, with a complaint of abnormal uterine bleeding, who hadn't benefited from medical treatment (oral progesterone, combined oral contraceptive, non steroid anti inflammatory drugs) or preferred LNG-IUS/RBEA treatment in the first place were randomized as sequenced according to the date of their application. Statistical power analysis is done, the number of patients is determined to be 61 with an accuracy of $\% 70$. Nevertheless, three patients had cervical stenosis and LNG-IUS couldn't be placed and the groups were determined in this manner to obtain the randomization. Primary endpoint is determined as one year follow-up time. In order to determine these patients, pelvic examination and transvaginal ultrasound (TVUSG) were performed for every patient applied with the complaint of menorrhagia in perimenopausal period; pregnency test is done. One month before the start of the treatment endometrial biopsi is taken by pipelle / full curettage method and Papanicolaou (Pap) smear test is done in order to eliminate any risk of malignancy. Endometrial biopsi / curettage results of the patients are reported as: In RBEA group, with seven patients simple non atypical endometrial hyperplasia, with fifteen patients estrogen (E2) effect, with seven patients progesterone effect, with two patients dysfunctional changes; in LNG-IUS group, with three patients simple non atypical endometrial hyperplasia, with thirteen patients estrogen (E2) effect, with seven patients progesterone effect, with four patients dysfunctional changes occured.

Inclusion criteria for the study are determined as: Being older than 35 , having a regular menstrual cycle, negative result for pregnancy test, not having a pelvic infection, having a score $>100$ in Pictorial bleeding assesment chart (PBAC), being negative for an abnormality in the cavity and suspicious endometrial pathology by TVUSG, not having an abnormal cervical or endometrial histology, not having a accompanying pathology that may require a hysterectomy operation (adnexal mass, uterine prolapse e.g.), having no contraindication for general anesthesia and having no wish for another child ${ }^{(11)}$. Consequently, the group with abnormal uterine bleeding is mainly composed of patients with dysfunctional uterine bleeding and patients with endometrial hyperplasia.

With twenty-seven patients having fulfilled these conditions, LNGIUS (Mirena, Schering Healthcare) was placed in the first fifteen days of their menstrual cycle by experienced doctors in various numbers under aseptic clinic conditions. Thirty-one patients had rollerball endometrial ablation by the same doctor under total intravenous anesthesia in an operating room. Endometrium preparing GnRH analogues weren't used by RBEA group.

PBAC scoring was made in order to rationalize the bleeding amount of patients. It was asked the patients to record daily the amount of fullness (little/medium/ much) of the pads and tampons used during menstruation. The scoring was made according to the 
amount of the pads and tampons the patients used and amount of their fullness. Patients are summoned for control by three month intervals. During the controls potential adverse effects and bleeding orders were investigated (Table I).

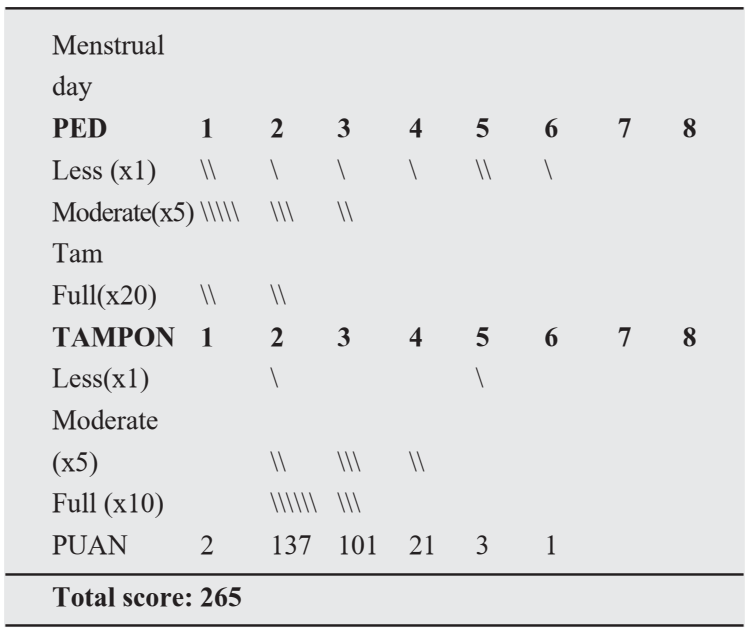

Figure 1: an example of pictorial bleeding assesment chart (PBAC).

Pictorial bleeding assesment chart (PBAC) scores and hemoglobin levels were noted pre-insertion/operatively and again at one year postinsertion/operatively. One year after the treatment, it was asked the patients, if they were satisfied with the effect of the treatment used to their bleeding problems. For statistical analysis, non-parametric tests (Mann- Whitney) and Pearson's chi-square test were used. Ethics Commitee approval was obtained for this study.

\section{RESULTS}

No statistical difference was found between the groups performed RBEA and Mirena, when ages, number of live births and durations of bleeding are compared $(\mathrm{p}>0.05)$ (Table I). Two patients $(\% 7)$ in Mirena group $(n=27)$ requested the instrument's removal at the end of three months due to their bleeding complaints going on and these patients were treated by hysteroscopic endometrial resection. At the end of one year, with seven cases $(\% 25)$ in Mirena group the treatment is thought to be unsuccessful, therefore three patients were performed hysterectomy $(\% 11)$, three patients (\%11) were performed hysteroscopic endometrial resection. One case $(\% 3)$ is solved by adding medical therapy (Tranexamic acid) to the treatment. The most common adverse effect due to use of LNG-IUS was vaginal bleeding in a manner of spotting, especially in the first three months. The attendance of patients with Mirena after one year was computed as \%66 (18/27), the amenorrhea rate was $\% 38.8(7 / 18)$, the hipomenorrhea rate was $\% 61.1(11 / 18)$, the satisfaction rate on bleeding patterns was \%62 (17/27) (Table II, III).

Table I: The basic features of participants.

\begin{tabular}{llllll}
\hline & $\begin{array}{l}\text { RBEA } \\
(\mathbf{n}=\mathbf{3 1})\end{array}$ & \multicolumn{2}{l}{$\begin{array}{l}\text { LNG-IUS } \\
(\mathbf{n}=\mathbf{2 7})\end{array}$} & $\begin{array}{l}\mathbf{p} \\
\text { value }\end{array}$ \\
\hline Age & $45(38-54)$ & 43 & $(36-52)$ & $(\mathrm{p}>0.05)$ \\
$\begin{array}{l}\text { Number of birth } \\
\begin{array}{l}\text { Duration of } \\
\text { menstruation (day) }\end{array}\end{array}$ & 4 & $(1-6)$ & 4 & $(1-5)$ & $(\mathrm{p}>0.05)$ \\
& $10-17)$ & 9 & $(6-15)$ & $(\mathrm{p}>0.05)$ \\
\hline
\end{tabular}

RBEA: Roller-band endometrial ablation, LNG-IUS: Levonergestrel intrauterin system.

Table II: Patient satisfaction after posttreatment first year, and hypomenorrhea and amennorrhoea

\begin{tabular}{llll}
\hline Post treatment & RBEA & LNG-IUS & p value \\
\hline Hypomenorrhea & $\% 70(17 / 24)$ & $\% 61.1(11 / 18)$ & 0.06 \\
Amennorrhoea & $\% 29(7 / 24)$ & $\% 38.8(7 / 18)$ & 0.08 \\
Patient satisfaction & $\% 70(22 / 31)$ & $\% 62(17 / 27)$ & 0.08 \\
\hline
\end{tabular}

RBEA: Roller-band endometrial ablation, LNG-IUS: Levonergestrel intrauterin system.

Table III: Continuation with the initial treatment at the end of the first year and additional venture notes(\%).

\begin{tabular}{llll}
\hline & RBEA & LNG-IUS & p value \\
\hline Continuation with the & & & \\
initial treatment & $24 / 30(\% 80)$ & $18 / 27(\% 66)$ & $>0.05$ \\
Medical therapy & - & $1 / 27(\% 3)$ & $>0.05$ \\
Hysteroscopic resektion & $4 / 30(\% 13)$ & $5 / 27(\% 18)$ & $>0.05$ \\
Hysterectomy & $2 / 30(\% 6)$ & $3 / 27(\% 11)$ & $>0.05$ \\
\hline
\end{tabular}

RBEA: Roller-band endometrial ablation, LNG-IUS: Levonergestrel intrauterin system.

One patient in RBEA group ( $\mathrm{n}=31$ ) didn't show up to the follow-ups. As a result of that six patients (\%19) had bleeding complaints going on, it was decided to make a re-operation. Four of those patients $(\% 13)$ were performed endometrial resection, two (\%6) were hysterectomized. One patient (\%3) had endometrial collection due to synechia, therefore was performed drainage using cervical dilatation. The attendance of patients with RBEA after one year was computed as $\% 80(24 / 30)$, the amenorrhea rate was $\% 29(7 / 24)$, the 
hipomenorrhea rate was $\% 70(17 / 24)$, the satisfaction rate on bleeding patterns was \%70 (22/31) (Table II, III).

The follow-up of the patients, who had simple non atypical endometrial hyperplasia as the result of endometrial pathology, was made measuring endometrial thickness by TVUSG and investigating bleeding symptoms.

In this group under RBEA and Mirena treatments, control endometrial sampling wasn't performed, because it wasn't recommended routinely, except of existance of an abnormal bleeding.

$\mathrm{The} \mathrm{Hb}$ consantration before the treatment was 9.9 $\mathrm{g} / \mathrm{dl}$ in the RBEA group (the standard deviation: 1,7), $10.2 \mathrm{~g} / \mathrm{dL}$ in the LNG-IUS group (the standard deviation: 1,6). After the treatment quantities of $\mathrm{Hb}$ were increased and the PBAC scores were decreased in both groups $(\mathrm{p}<0.05)$ compared to the pre-treatment results, nevertheless no significant difference could be found between the groups. $(\mathrm{p}>0.05)$ (Table IV, V).

Table IV: Hb values pre and post treatment (mean standart deviation) $(g / d L)$.

\begin{tabular}{llllllll}
\hline & \multicolumn{3}{c}{ RBEA } & & LNG-IUS & p \\
\hline $\begin{array}{l}\text { Pre treatment } \\
\begin{array}{l}\text { At the end of } \\
\text { first year }\end{array}\end{array}$ & $\mathrm{n}=31$ & 9.9 & 1.7 & $\mathrm{n}=27$ & 10.2 & 1.6 & $>0.05$ \\
\hline
\end{tabular}

RBEA: Roller-band endometrial ablation, LNG-IUS: Levonergestrel intrauterin system.

Table V: change in the PBAC score pre and post treatment.

\begin{tabular}{|c|c|c|c|c|c|}
\hline & $\begin{array}{l}\text { RBE } \\
\text { A }\end{array}$ & PBAC & $\begin{array}{l}\text { LNG- } \\
\text { IUS }\end{array}$ & PBAC & $\mathbf{p}$ \\
\hline Pre treatment & $\mathrm{n}=31$ & $\begin{array}{l}440 \\
(145-1360)\end{array}$ & $\mathrm{n}=27$ & $\begin{array}{l}480 \\
(135-1400)\end{array}$ & $>0.05$ \\
\hline $\begin{array}{l}\text { At the end of } \\
\text { first year }\end{array}$ & $\mathrm{n}=24$ & $55(0-95)$ & $\mathrm{n}=18$ & $70(0-100)$ & 0.04 \\
\hline
\end{tabular}

RBEA: Roller-band endometrial ablation, LNG-IUS: Levonergestrel intrauterin system, PBAC: pictorial blood loss assesment chart.

\section{DISCUSSION}

Although the exact mode of treatment in patients diagnosed abnormal uterine bleeding who don't respond to medical treatment is hysterectomy; today, alternative treatment options are available which are effective and less invasive. According to the results of our study (levels of $\mathrm{Hb}$ and PBAC scores) RBEA and LNGIUS both are effective in the treatment of abnormal uterine bleeding.

According to the results of the only study in literature, in which RBEA and LNG-IUS methods were compared prospectively in the treatment of treatment-resistant hypermenorrhea, the amenorrhea rates were found as $46 \%$ and $40 \%$ by order, the satisfaction rate was $93 \%$ and $73 \%$; still no statistical difference could be found between the groups, same as the results of our study(12). The rate of amenorrhea after ablation was $\% 47.8$ in the study of Rosati M. at al.,but in our series it is $\% 29(7 / 24)^{(13)}$. Not using GnRH analogues preparing the endometrium or progesterone withdrawal bleeding with patients used RBEA resulted in, that lower amenorrhea rates were found than expected; and in cases which we used GnRH agonist before endometrial resection have achieved better results which will be shown later. In a study of 2,5 year followed 200 cases of roller-ball ablation the results shows $90 \%$ success rate, $4 \%$ the necessity of repeat of the procedure and $5 \%$ rate of hysterectomy $(14)$. In our own study, in the group with treatment failure 2 patients (\%6) were performed hysterectomy in RBEA group, such as 3 patients (\%11) in LNG-IUS group. Accordingly, less need for major surgical intervention is seen in RBEA group, but any sufficient evidence for statistically significant differences weren't found. A prospective, non-randomized study, in which 63 patients suffering from menorrhagia had been followed 4 year long after been applied LNG-IUS, has a result of a $28,5 \%$ rate of amenorrhea, $71,4 \%$ rate of continuity of treatment and $15,8 \%$ rate of additional interference (hysterectomy) as a result of treatment failure ${ }^{(15)}$. In our series, 4 patients in RBEA group (13\%), 5 patients in LNGIUS group (18\%) were treated with hysteroscopic endometrial resection due to treatment failure. In this way, patients were protected from major surgical interventions. In both groups, if a failure in treatment occurs, hysteroscopic resection should be considered as a last option before hysterectomy.

Not having any pre-op complications in RBEA group, having $30 \mathrm{~min}$. maximum as operating time and the same day patient discharging prove the reliability and the velocity of procedure due to the experienced hands.

The eligibility of LNG-IUS to RBEA comes from its recyclability, fertility protection and being also a 
contraceptive method. Although being a contraceptive method due to destruction of the endometrium, endometrial ablation can not be used for contraception even if it has negative affect on implantation of the pregnancy product. In addition, RBEA is an invasive precedure requiring an experienced gynecologist with surgical equipment and operating room and environment of operating under anesthesia, but LNGIUS is a much simple method, because it can be performed by trained general practitioners in clinics without using anesthesia. Although there could be seen some systemic side effects by LNG-IUS method, they are mostly slight effects and the device utilization rate can be increased by contacting the patient. Consequently, both methods are similarly succesful in abnormal uterine hemorrhage and the choice between them must done according to the needs and will of the patients.

\section{REFERENCES}

1. Stewart A, Cummins, Gold L, Jordan R, Philips W. The effectiveness of the levonorgestrel-releasing intrauterine system in menorrhagia: a systematic review. Br J Obste Gynaecol 2001; 108: 74- 86.

2. Monteiro I, Bahamondes L, Diaz J, Perrotti M, Petta C. Therapeutic use of levonorgestrel releasing intrauterine system in women with menorrhagia: a pilot study. Contraception 2002; 65: 325- 8 .

3. Bradlow J, Coulter A, Brooks P. Patterns of referrral. Oxford: Health Services Research Unit; 1992

4. Lethaby A, Hickey M. Endometrial destruction techniques for heavy menstrual bleeding. Cochrane Database Sys Rev 2002(2): CD001501.

5. Clarke A, Black N, Rowe P, Mott S, Howle K. Indications for and outcome of total abdominal hysterectomy for benign disease: a prospective cohort study. Br J Obstet Gynaecol 1995; 102: 611- 20

6. Maresh MJA, Metcalfe MA, McPherson K, Overton C, Hall V, Hargreaves J, et al. The VALUE national hysterectomy study: description of the patients and their surgery. BJOG 2002; 109: 302- 12 .

7. Banu NS, Manyonda IT. Alternative medical and surgical options to hysterectomy. Best Pract Res Clin Obstet Gynaecol 2005; 9: 431- 49 .

8. Scottish Hysteroscopy Audit Group. A Scottish audit of hysteroscopic surgery for menorrhagia: Complications and follow up. Br J Obstet Gynaecol 1995; 102: 249- 54.

9. Römer Th. Die transzervikale Endometriumablation mit der Roller-Ball-Methode- Eine Alternative zur Hysterektomie bei therapieresistenten rezidivierenden Hypermenorrhoen? - Erste Er- fahrungen. Geburtsh u Frauenheilk 1994; 54: 213- 5.

10. Hurskainen R, Teperi J, Rissanen P, Alto AM, GGrenman S, Kivela A, et al. Clinical outcomes and costs with levonorgestrelreleasing intrauterine system or hysterectomy for treatment of menorrhagia. Randomized trial 5 years follow up. JAMA 2004; 291: 1456- 63

11. Higham JM, O'Brien PMS, Shaw RW. Assesment of menstrual blood loss using a pictorial chart. Br J Obstet Gynaecol 1990; 97: 734- 9 .

12. Thomas Römer. Prospective comparison study of levonorgestrel IUD versus Roller-Ball endometrial ablation in the management of refractory recurrent hypermenorrhea.

13. Rosati M, Vigone A, Capobianco F, Surico D, Amoruso E, Surico N. Long-term outcome of hysteroscopic endometrial ablation without endometrial preparation. Eur J Obstet Gynecol Reprod Biol. 2008 Jun; 138(2): 222- 5.

14. Paskowitz RA. Rollerball ablation of the endometrium. J Repr Med 1995; 40: 333- 6 .

15. Kriplani A, Singh B.M, et al. Efficacy, acceptability and side effects of the levonorgestrel intrauterine system for menorrhagia. International Journal of Gynecology and Obstetrics 2007; 97: 190- 4 